Fikrah: Jurnal Ilmu Aqidah dan Studi Keagamaan

ISSN 2354-6147 EISSN 2476-9649

Tersedia online di: journal.stainkudus.ac.id/index.php/fikrah

DOI: 10.21043/fikrah.v5i1.2181

\title{
Potensi Keberagamaan Masyarakat Kudus: Upaya Memperkuat Ideologi Pancasila Melalui Local Wisdom
}

\author{
Atika Ulfia Adlina \\ STAIN Kudus, Jawa Tengah, Indonesia \\ adlinautsman@gmail.com
}

\begin{abstract}
Abstrak
Masyarakat beragama di Indonesia perlu diberdayakan untuk meningkatkan kualitas keberagamaannya. Pemberdayaan masyarakat beragama ini untuk menjaga persatuan dan kerukunan antar umat beragama yang hidup di Indonesia. Sebab dengan meningkatkan keberagamaan akan memperkuat ideologi Pancasila sebagai budaya bangsa sehingga bangsa Indonesia mampu menghadapi dampak globalisasi yang begitu massif. Dampak yang terlihat seperti perubahan cara hidup, gaya hidup, krisis identitas yang dapat memicu degradasi moral bangsa. Jenis penelitian ini adalah penelitian kualitatif deskriptif. Hasil kajian ini menunjukkan bahwa masyarakat beragama merupakan potensi yang penting untuk diberdayakan dalam rangka penguatan ideologi Pancasila. Pemberdayaan masyarakat beragama dapat dilakukan melalui atribut-atribut keagamaan dan kearifan lokal.
\end{abstract}

Keyword: Pemberdayaan masyarakat beragama, nilai universal agama, kearifan lokal, ideologi Pancasila. 


\begin{abstract}
The religious community in Indonesia need to be empowered to improve the religiosity of it quality. This religious community empowerment to maintain unity and harmony between religious livings in Indonesia. Increasing the religiosity will strengthen the Pancasila ideology of as the culture of the nation so that the massive impact of globalization reduced. The impact of globalization like changing ways of live, lifestyle, identity crisis that could trigger the morality degradation. This type of research is a qualitative descriptive study. The results of this study show that the religious community is an important potential for empowered in the framework of strengthening ideology of Pancasila. The religious community empowerment can be done via religious attributes and local wisdom.
\end{abstract}

Keyword: Empowerment of Religious Community, universal value of religion, local wisdom, ideology of Pancasila.

\title{
Pendahuluan
}

Salah satu dampak dari globalisasi adalah lunturnya ideologi Pancasila. Hal tersebut disebabkan adanya perubahan cara hidup, gaya hidup (lifestyle), dan pandangan hidup (worldview) yang pada akhirnya mengancam eksistensi berbagai bentuk warisan adat, kebiasaan, nilai, identitas dan simbol-simbol yang berasal dari budaya lokal. Berbagai perubahan tersebut merupakan dampak dari perkembangan kehidupan masyarakat di era global melalui berbagai teknologi (teknologi informasi, telekomunikasi, televisi, internet), berbagai agen (kapitalis, produser, artis) dan berbagai produk (barang, tontotan, hiburan).

Mulai hilangnya ideologi Pancasila yang merupakan budaya bangsa berdampak pada menurunnya semangat nasionalisme yang ditandai dengan renggangnya rasa persaudaraan di masyarakat. Hidup dalam satu negara, satu daerah tetapi satu dengan yang lain merasa asing dan individualistik ditambah dengan gaya hidup hedonisme sehingga degradasi moral semakin meningkat ditandai dengan tindak kriminalitas, kekerasan, perkosaan, pornografi dan pelecahan seksual.

Bangsa Indonesia yang mengakui kebenaran agama sebagai alat kontrol moralitas, harus didorong untuk menggerakkan budaya bangsa (local wisdom) untuk mengantisipasi degradasi moral bangsa yang semakin meningkat tajam. Antara Pancasila dan agama tidak ada perdebatan yang serius. Terlebih nilai dan ajaran agama menjadi dasar dari terbentuknya Ideologi Pancasila yang bermuara pada nilai-nilai 
universal, nilai-nilai yang menjadi hakikat manusia sehingga siapapun dan dari agama manapun, nilai tersebut tetap sama.

Adanya kesenjangan antara ajaran agama dengan pemahaman dan pengamalannya menyebabkan kualitas keberagamaan bangsa Indonesia secara tidak langsung tidak cukup efektif menjadikan agama sebagai alat kontrol moralitas. Oleh karena itu, mengaktualisasikan nilai-nilai universal perlu diberdayakan oleh masyarakat beragama melalui atribut-atribut yang dimiliki agama. Mengaktualkan ajaran agama secara kontekstual terlibat aktif dalam sendi kehidupan manusia, bukan menampilkan dirinya sebagai sosok yang eksklusif. Al-quran menunjukkan ketidaksetujuannya terhadap sikap eksklusivitas sebagian kelompok sebagaimana tersirat dalam surat attaubah ayat 6:

"Dan jika seorang diantara orang-orang musyrikin itu meminta perlindungan kepadamu, maka lindungilah ia supaya ia sempat mendengar firman Allah, kemudian antarkanlah ia ketempat yang aman baginya. Demikian itu disebabkan mereka kaum yang tidak mengetahui”. (Q.S At Taubah: 6)

Masyarakat perlu didorong untuk aktif terlibat dalam setiap segmen kehidupan manusia, berkiprah di ranah ekonomi, sosial, pendidikan, seni dan budaya dengan berbasis nilai-nilai universalnya.

Kota Kudus merupakan kota percontohan di mana kemajemukan masyarakat berdasarkan agama, etnis, pekerjaan dan budaya dapat melebur menjadi sebuah kehidupan yang harmonis. Dulu masyarakat Kudus, muslim utamanya terkenal akan toleransinya tidak mengkonsumsi daging sapi sebagai penghormatan terhadap kepercayaan umat hindu terhadap binatang sapi. Kini meski tradisi tidak mengkonsumsi daging sapi di kalangan masyarakat kudus sudah mulai menghilang dengan semakin meningkatnya masyarakat kudus yang konsumsi daging sapi, toleransi masyarakat kudus bergeser kepada tradisi yang lain seperti mempersilahkan umat kristiani membunyikan lonceng gereja pada hari jumat pagi. Tulisan ini bertujuan untuk mendeskrisikan secara kritis peran masyarakat beragama di Kudus dalam rangka memperkuat ideologi bangsa melalui pemanfaatan atribut keagamaan dengan pendekatan local wisdom. 


\section{Metode Penelitian}

Jenis penelitian yang digunakan adalah penelitian kualitatif dengan pendekatan deskriptif. Fokus penelitian ini adalah pertama, prinsip-prinsip ajaran dalam setiap agama yang mengandung nilai-nilai universal. Potensi keberagamaan yang ada dalam setiap ajaran agama tersebut memiliki relevansi yang kuat dengan ideologi pancasila yaitu prinsip keagamaan yang bermuara pada nilai-nilai yang menjunjung tinggi harkat dan martabat manusia sebagimana tertuang dalam butir sila dalam pancasila. Kedua, ragam pemberdayaan masyarakat beragama di kudus baik melalui atribut keagamaan seperti pemberdayaan tempat tempat peribadatan, lembaga dakwah, lembaga pendidikan agama dan tradisi-tradisi sebagai bentuk dari local wisdom.

\section{Nilai-nilai Universal dalam Pancasila dan Agama-agama di Indonesia}

Nilai-nilai universal secara umum diyakini kebenarannya oleh semua kalangan. Ginanjar (2004, hal. 160) menyebut nilai-nilai universal sebagai sifat dasar spiritual manusia seperti kemampuan manusia untuk menyayangi, menghargai sesama, keadilan, kejujuran, kemuliaan, kasih sayang, tanggung jawab dsb.

Megawangi (2004, hal. 95) dalam tesisnya merangkum berbagai teori dan menuangkan nilai-nilai universal ke dalam sembilan pilar, yaitu: (1) cinta Tuhan dengan segala ciptaannya (love Allah, trust, reverence, loyalty), (2) kemandirian dan tanggung jawab (responsibility, excellence, self reliance, dicipline, orderliness), (3) kejujuran, amanah dan bijaksana (trustworthiness, reliability and honesty), (4) hormat dan santun (respect, courtessy, obedience), (5) dermawan suka menolong dan gotong royong (love compassion, caring empathy, generousity, moderation, cooperation), (6). Percaya diri kreatif dan pekerja keras (confidence, assertiveness, creativity, resourcefullness, courage, determination, and enthusiasm), (7) kepemimpinan dan keadilan (justice, fairness, mercy, leadership, (8) baik dan rendah hati (kindness, friendliness, humility, modesty), dan (9) toleransi, kedamaian dan persatuan (tolerance, flexibility, peacefullness, unity).

Toto Tasmara (2001) dalam bukunya "Kecerdasan Ruhaniah" mengemukakan bahwa nilai-nilai yang perlu dikembangkan dalam jiwa seseorang, antara lain: 
Pertama, the man of wisdom. Mereka tidak hanya menguasai dan terampil mekasanakan profesinya, tetapi juga sangat berdedikasi dan dibekali dengan hikmah kebijakan (Q.S Al Baqarah 2: 269). Kedua, High in integrity. Bersungguh-sungguh dalam segala hal, khususnya dalam meningkatkan kualitas keilmuwan dirinya (Q.S Ali Imran 3: 190). Ketiga, Willingnes to learn. Memiliki motivasi dangat kuat untuk terus belajar dan mampu mengambil pelajaran dari setiap peristiwa yang dihadapinya (Q.S 12: 111). Keempat, Proactive Stance. Bersikap proaktif, ingin memberikan kontribusi positif bagi lingkungannya. (Q.S. Al Maidah 5: 110). Kelima, Faith in God. Sangat mencintai Tuhannya dan karenanya selalu mendapat petunjuk dariNya (Q.S Al Baqarah 2: 138). Keenam, Creditable and reputable. Selalu berusaha untuk menempatkan dirinya sebagai insan yang dapat dipercaya sehingga tidak pernah mau mengingkari janji atau mengkhianati amanah yang dipikulkan kepada dirinya (Q.S. Ar Ra'd 13: 19-22). Ketujuh, Being the best. Selalu ingin menjadikan dirinya sebagai teladan dan menampilkan unjuk kerja yang terbaik (Q.S Ali Imran 3: 110). Kedelapan, Empathy and Compassion. Menaruh cinta kepada orang lain (Q.S. at Taubah 9: 128). Kesembilan, Emotional Majurity. Memiliki kedewasaan emosi, tabah dan tidak pernah mengenal kata menyerah serta mampu mengendalikan diri dan tidak pernah terperangkap dalam keputusan emosional (Q.S. Luqman 31: 17). Kesepuluh, Balance. Memiliki jiwa yang tenang, sebagaimana dikenal dalam al quran sebagai nafsu muthmainnah (Q.S Al Fajr 89: 27-30). Kesebelas, Sense of mission. Memiliki arah tujuan atau misi yang jelas dalam hidupnya (Q.S Ash Shaff 2:9). Keduabelas, Sense of Competition. Mereka memiliki sikap untuk bersaing dengan sehat (Q.S Al Baqarah 2: 148).

Nilai-nilai universal tersebut jelas terangkum dalam Pancasila sebagai satusatunya pilihan dalam rangka memelihara keutuhan bangsa dan negara, serta pencapaian cita-cita nasional, yaitu negara Indonesia yang merdeka, bersatu, berdaulat, adil dan makmur (Sutaryo, Jaya, Swasono, Baswir, \& Prijambada, 2015, hal. 11). Sila Ketuhanan Yang Maha Esa, (Nurhadianto, 2014, hal. 53-55) memuat nilai-nilai berupa pertama, bangsa Indonesia menyatakan kepercayaannya dan ketakwaannya terhadap Tuhan Yang Maha Esa. Kedua, Manusia Indonesia percaya dan takwa terhadap Tuhan yang Maha Esa, sesuai dengan agama dan kepercayaannya masing-masing menurut dasar kemanusiaan yang adil dan beradab. Ketiga, Mengembangkan sikap hormat 
menghormati dan bekerja sama antara pemeluk agama dengan penganut kepercayaan yang berbeda-beda terhadap Tuhan Yang Maha Esa. Keempat, Membina kerukunan hidup di antara sesama umat beragama dan kepercayaan terhadap Tuhan Yang Maha Esa. Kelima, Agama dan kepercayaan terhadap Tuhan Yang Maha Esa adalah masalah yang menyangkut hubungan pribadi manusia dengan Tuhan Yang Maha Esa. Keenam, Mengembangkan sikap saling menghormati kebebasan menjalankan ibadah sesuai dengan agama dan kepercayaannya masing-masing. Ketujuh, Tidak memaksakakan suatu agama dan kepercayaan terhadap Tuhan Yang masa Esa kepada orang lain.

Berikutnya sila kedua, yakni Kemanusiaan yang adil dan beradab memiliki nilainilai sebagai berikut pertama, Mengakui dan memperlakukan manusia sesuai dengan harkat dan martabatnya sebagai makhluk Tuhan Yang Maha Esa, kedua, Mengakui persamaan derajat, persamaan hak dan kewajiban asasi setiap manusia tanpa membedabedakan suku, keturunan, agama, kepercayaan, jenis kelamin, kedudukan sosisla, warna kulit dan sebagainya. Ketiga, Mengembangkan sikap saling mencintai sesama manusia. Keempat, Mengembangkan sikap saling tenggang rasa dan tepa selira. Kelimat, Mengembangkan sikap tidak semena-mena terhadap orang lain. Keenam, Menjunjung tinggi nilai-nilai kemanusiaan. Ketujuh, Gemar melakukan kegiatan kemanusiaan. Kedepalan, Berani membela kebenaran dan keadilan. Kesembilan, Bangsa Indonesia merasa dirinya sebagai bagian dari seluruh umat manusia. Kesepuluh, Mengembangkan sikap hormat menghormati dan bekerjasama dengan bangsa lain.

Sila ketiga, Persatuan Indonesia memiliki nilai-nilai, pertama, Mampu menempatkan persatuan, kesatuan, serta kepentingan dan keselamtan bangsa dan negara sebagai kepentingan bersama di atas kepentingan pribadi dan golongan. Kedua, Sanggup dan rela berkorban untuk kepentingan negara dan bangsa apabila diperlukan. Ketiga, Mengembangkan rasa cinta kepada tanah air dan bangsa. Keempat, Mengembangkan rasa kebanggan berkebangsaan dan bertanah air Indonesia. kelima, Memelihata ketertiban dunia yang berdasakan kemerdekaan, perdamaian abadi dan keadilan sosial. Keenam, Mengembangkan persatuan Indonesia atas dasar Bhineka Tunggal Ika. Ketujuh, Memajukan pergaulan demi persatuan dan kesatuan bangsa. 
Sila Keempat, Kerakyatan yang Dipimpin oleh Hikmah Kebijaksaan dalam Permusyawaratan Perwakilan. Sila ini menegaskan bahwa demokrasi Indonesia adalah demokrasi permusyawaratan yang merupakan kedaulatan rakyat. Sila kelima, Keadilan Bagi Seluruh Rakyat Indonesia, yang menegaskan bahwa keadilan sosial harus ditegakkan dalam bingkai kemanusiaan dan demokrasi permusyawaratan.

Sementara dalam konteks agama, Biksu Sri Prannavaro Mahathera, Kepala Sangha Theravada Indonesia dalam diskusi peluncuran buku "Agama, Moral dan Masa Depan Bangsa”, mengungkapkan bahwa meski memiliki teologi berbeda, semua agama mendorong umat memperkuat nilai-nilai kemanusiaan universal dan moral etik. Para tokoh agama berpotensi untuk mendidik bangsa agar berperilaku baik. Namun, semua itu tidak bisa dicapai secara otomatis dengan sekedar memiliki agama (Liauw, 2015). Demikian juga uraian Ahmad Syafii Maarif, mantan Ketua Umum Pengurus Pusat Muhammadiyah, dalam kesempatan yang sama menuturkan bahwa agama yang mengabaikan persoalan kemanusiaan akan ditinggalkan pengikutnya sekalipun para pemimpin agama itu fasih mengutip teks-teks suci. Begitu pula agama di tangan pengikut yang terlepas dari kawalan moral justru memicu kegaduhan dan konflik. Untuk itu, perlu dikembangkan sikap beragama yang mementingkan kemanusiaan universal (Liauw, 2015).

Dalam Hinduisme dan Budhiisme, ada tiga komponen moral yang perlu ditanamkan dalam diri manusia yaitu, sila (akhlaq), Samaddi (Perkembangan mental), dan Panna (kebijaksanaan). Kebaikan moral atau sila dapat ditempuh melalui perkataan, perbuatan dan pekerjaan yang dilakukan secara baik dan benar. Sila ini kemudian dirumuskan menjadi lima hal (pancasila) yang terdiri dari menanamkan sifat penyayang terhadap makhluk hidup, tidak makan minum benda yang memabukkan dan merusak akal sehat, bersifat jujur dan tidak merampas hak orang lain, bercakap jujur dan tidak fitnah memfitnah, tidak melakukan hubungan perzinaan dan perkara yang merusak moral remaja. Samaddi dapat ditempuh melalui usaha, kesadaran, dan kesimpulan yang benar. Panna diperoleh melalui pemahaman dan pemikiran yang benar (Aziz, 2004, hal. 6). Sistem nilai dan etika dalam ajaran kristiani termuat dalam kitab Old Testement dan new testement. Sistem nilai kehidupan sehari-hari terangkum dalam the ten commandments (dalam Old Testement), yaitu sebagai berikut: 
The ten Commandments mengemukakan sepuluh nilai moral yang mesti dihayati oleh penganut kristian antaranya: mempercayai konsep Trinity (Son of God, Father of God, ruhul Qudus), tidak menyembah patung atau berhala yang menyerupai objek di langit dan di bumi, tidak menyebut nama Tuhan secara sembarangan, tetaplah ingat dan mensucikan hari sabath, menghormati ayah dan ibu, jangan membunuh, jangan berzina dan melakukan maksiat, jangan mencuri, jangan berdusta, jaga hak asasi orang lain.

Nilai-nilai dalam kehidupan sehari-hari yang terkandung dalam New Testement adalah jangan menghina orang lain, mengutamakan etika, jangan menipu, mencari keridhoan Tuhan, menjadikan Yesus sebagai teladan, bersikap ramah dan pemberani, menjauhi tujuh perkara haram (membunuh, berbohong dll), menjelaskan kebenaran, tidak serakah, mencintai orang lain seperti diri sendiri. Sementara dalam pembentukan pemikiran masyarakat dan tamadun Cina banyak diwarnai oleh falsafah etika dan kehidupan yang diperlopori oleh Kun Fu Tze. Dua fokus utama dalam membahas persoalan etika dan kehidupan yang dikemukakan oleh Confucius adalah Lima kebaikan dan lima hubungan. Lima kebaikan membawa makna perikemanusiaan di antaranya, bersopan santun, hati terbuka, kejujuran dan sifat amanah yang terpuji, ketekunan dan bersifat lemah lembut. Sementara lima hubungan menjelaskan bagaimana seseorang harus berhubungan dengan orang-orang di sekitar, seperti sikap taat dan setia terhadap pemerintahan, kasih sayang terhadap orang tua, menghormati dan menyayangi terhadap saudara, saling menjaga kehormatan dan bertanggung jawab dalam hubungan suami istri, serta bersikap ikhlas dan jujur terhadap hubungan antar kawan atau patner kerja.

Dimensi hidup kemanusiaan yang sarat nilai-nilai universal dalam ajaran Islam (Solikhin, 2015, hal. 16) antara lain Silaturahmi, pertautan rasa cinta dan kasih kita kepada sesama manusia. Ukhuwah (persaudaran), harus ada keterikatan persaudaran yang kental. Al Musawwamah (persamaan): sikap pandangan bahwa manusia adalah sama kecuali pada dimensi ketaqwaan. Adil, wawasan pola euilibriumitas, pola keseimbangan, tidak bersikap apriori dalam segala hal. Berbaik sangka. Tawadhu, rendah hati. Al wafa, Menepati janji atau amanah. Insyirah, lapang dada. Iffah, perwira. Qawamiyah, hemat dan Al munfiqun, dermawan 


\section{Aktualisasi Nilai-nilai universal Agama dalam Keberagamaan Masyarakat Antisipasi Degradasi Moral}

Degradasi moral adalah kemerosotan atas budi pekerti seseorang maupun sekelompok orang misalnya sikap acuh tak acuh, individualistik, sikap hedonisme, berorientasi pada materiil semata dsb yang berujung pada berbagai macam tindakan kriminalitas, pornografi, kekerasan dsb. Paling tidak ada tujuh faktor-faktor penyebab degradasi moral bangsa (Muthohar, 2013, hal. 326) yaitu pertama, Tersebar luasnya pandangan materialistis tanpa spiritualitas, ukuran kesuksesan lebih diukur pada kesuksesan materiil dan mengesampingkan moralitas. Kedua, Konsep moralitas kesopanan menjadi longgar karena pengaruh budaya barat akibat dari mudahnya mencari informasi melalui ICT. Ketiga, Budaya global menawarkan kenikmatan semu melalui Food, fashion dan fun. Keempat, Tingkat persaingan semakin tinggi karena terbukanya sekat lokal dan kebanyakan bersifat online. Kelima, Masyarakat lebih bersifat individualistis dan kurang peduli dengan lingkungannya sehingga kontrol moral menjadi rendah. Keenam, Keluarga kurang dapat memberi pengarahan karena masing-masing orang tua sudah mempunyai kesibukannya sendiri atau bahkan broken home. Ketujuh, Sebagian besar sekolah tidak sepenuhnya dapat mengontrol perilaku siswa, karena keterbatasan waktu, sumber daya dan sumber dana ataupun kurang mementingkan moralitas. Dengan demikian dapat disimpulkan bahwa pengaruh lingkungan yang buruk, ditambah dengan kontrol diri dan kontrol sosial yang semakin melemah dapat mempercepat peningkatan degradasi moral bangsa.

Dalam rangka memperkuat ideologi pancasila sebagai budaya bangsa, masyarakat beragama perlu mengevaluasi dan mengupgrade pola keberagamaannya, agar nilai-nilai universal yang ada pada setiap agama mampu terangkat. Untuk dapat meningkatkan kualitas keberagamaan masyarakat, perlu dilakukan melalui pemberdayaan masyarakat beragama.

\section{Potensi Keberagamaan Masyarakat di Kudus}

Pemberdayaan sebagai konsep sosial budaya yang implementatif dalam pembangunan yang berpusat pada rakyat, kini tidak lagi ditujukan pada menumbukembangkan added vallue ekonomi, tetapi juga nilai-nilai sosial budaya. 
Pendekatan pembangunan yang berpusat pada rakyat berusaha untuk membangkitkan kesadaran akan pentingnya keberadaan dan tatanan sosial mereka yang sebelumnya pernah ada. Wujud-wujud organisasi yang pernah ada atas dasar pemenuhan kebutuhan praktis adalah awal dari metode pemberdayaan dan celah untuk masuk ke sistem sosial masyarakat. Kebutuhan praktis yang dimaksud adalah kebutuhan dasar manusia (“Teknik Pemberdayaan Masyarakat Secara Partisipatif,” 2002, hal. 1)

Pemberdayaan masyarakat dikenal sebagai strategi pembangunan yang berdimensi kerakyatan. Pembangunan berdimensi kerakyatan dan pemberdayaan masyarakat memiliki paradigma yang sama yaitu pembangunan yang menekankan aspek manusia dan masyarakatnya dibanding unsur lain. Kartasasmita (Nurjamila, 2016, hal. 95) menjelaskan tahapan-tahapan yang umumnya dilakukan dalam upaya pemberdayaan masyarakat adalah pertama, menciptakan suasana atau iklim yang memungkinkan potensi masyarakat berkembang (enabling). Pada tahap ini titik tolaknya adalah pengenalan bahwa setiap manusia, setiap masyarakat, memiliki potensi yang dapat dikembangkan. Dalam konteks nilai-nilai universal, masyarakat memiliki potensi hati nurani yang menjadi fitrah manusia yang dapat diberdayakan kembali.

Kedua, memperkuat potensi atau daya yang dimiliki masyarakat (empowering). Pada tahap ini diperlukan langkah-langkah positif, selain dari hanya menciptakan iklim dan suasana. Langkah positif dimaksud meliputi langkah-langkah nyata, dan menyangkut penyediaan berbagai masukan (input), serta pembukaan akses ke dalam berbagai peluang (opportunities) yang akan membuat masyarakat menjadi berdaya. Ketiga, memberdayakan yang juga mengandung arti melindungi, harus dicegah dari yang lemah menjadi betambah lemah oleh karena kekurangberdayaan dalam menghadapi yang kuat. Pemihakan terhadap yang lemah harus menjadi prioritas dalam pemberdayaan masyarakat.

Sementara pemberdayaan masyarakat beragama berarti diarahkan pada strategi memberdayakan potensi keberagamaan masyarakat. Potensi keberagamaan masyarakat yang dibangun adalah bukan pada dimensi keakidahan akan tetapi lebih pada nilai-nilai universal yang dimiliki oleh setiap agama. Pada tataran praktis, pemberdayaan masyarakat beragama dapat juga ditempuh melalui pengelolaan yang berbasis 
pemberdayaan beberapa atribut keagamaan yang masing-masing agama miliki misalnya tempat-tempat peribadatan, metode dakwah, lembaga pendidikan, dan lembaga sosial keagamaan.

Pendekatan pemberdayaan masyarakat beragama dapat bersifat improvement atau transformasi tergantung bagaimana dinamika karakter dan budaya masyarakat di suatu wilayah. Indardi (2016, hal. 53) mengungkapkan bahwa perlu kajian secara cermat oleh para praktisi tentang pembangunan baik oleh pemerintah ataupun change agent lain yang ada di daweah-daweah, sub-sub sistem mana yang dipandang sudah baik, sudah berjalan secara efektif dan efisien sesuau dengan fungsinya. Dicermati pula subsub sistem yang relatif sudah baik dan befungsi sebagaimana mestinya, baik itu di level pemerintah, lembaga swasta, maupun kelembagaan di tingkat maka pemberdayaan masyarakat bisa dilakukan secara improvement. Sementara pada sub-sub sistem yang sama sekali tidak berfungsi, justru bersifat parasit terhadap sistem yang ada secara keseluruhan maka disarankan pemberdayaan pada lembaga-lembaga ini dilakukan secara transformation dengan tetap memperhatikan kondisi sosial-politik dan budaya masyaarakat sehingga dinamika yang ada tidak menjurus pada situasi yang chaos. Dengan demikian pemberdayaan masyarakat beragama secara selektif yang merupakan kombinasi dari keduanya adalah pilihan yang relatif bijak, dengan memperhatikan situasi dan kondisi sehingga perubahan yang diharapkan dari pembangunan betul-betul ke arah kemajuan (progress), bukan kemunduran yang akhirnya merusak tatanan sosialekonomi dan budaya masyarakat yang sudah ada.

\section{Pemberdayaan Masyarakat Beragama Melalui Tempat-tempat Peribadatan}

Pemberdayaan tempat-tempat peribadatan selama ini, masih berorientasi pada kegiatan peribadatan saja. Kegiatan-kegiatan yang sering dilakukan di masjid atau juga gereja misalnya masih hanya berupa sholat berjamaah dan pengajian hari-hari besar keagamaan. Kegiatan di beberapa masjid masih sepi dengan aktifitas sosial misalnya dijadikannya masjid untuk tempat menuntut ilmu, diskusi, rapat RT, aktifitas ekonomi di sekililing masjid, tempat bermain di lingkungan masjid, tempat olahraga di lingkungan masjid, penyelenggaraan forum diskusi lintas agama dan lain sebagainya 
yang menempatkan masjid sebagai basis aktifitas sosial masyarakat. Pengelolaan masjid sebagai basis aktifitas sosial tersebut tentu saja dapat dijadikan media mengaktualisasikan nilai-nilai universal seperti gotong royong, ramah, tanggung jawab, kemandirian, tenggang rasa, toleransi, kedamaian dan persatuan.

Jeffery Cox dalam Conolly (2009, hal. 291) mengidentifikasi kesuksesan Gereja dalam menghadirkan para Jama'ahnya sehingga memiliki tingkat kehadiran yang tinggi, lebih berdasar pada tingkat keluasan aktifitas gereja terhadap aktifitas sosial, pendidikan dan liturgis, yang perkembangannya didukung oleh gereja, meliputi organisasi persatuan pemuda, serikat kerja pelayan altar, dan anak laki-laki yang tergabung dalam paduan suara gereja, sekolah-sekolah Minggu, kelompok-kelompok studi pendidikan dan Injil bagi orang muda dan tua, aktifitas peribadatan pertengahan Minggu dan proses liturgis di seluruh kota. Sementara gereja yang besar, dingin, dan kosong dengan sendirinya menjadi faktor penghambat kehadiran jema'at di gereja secara regular.

Survey Grace Davie dalam Conolly (2009) juga menyebutkan bahwa jurang antara responden yang hadir di gereja dan mereka yang tetap meyakini Tuhan dan mempraktekkan berbagai bentuk aktifitas keagamaan privat di rumah, menunjukkan bahwa penurunan tingkat kehadiran di gereja bukan berarti ditinggalkannya agama begitu saja. Akan tetapi, lebih merupakan menurunnya partisipasi publik dalam bentuk institusional dan kembali memfokuskan aktifitas keagamaannya di rumah yang mencerminkan tersebar luasnya rasa tidak percaya terhadap institusi-institusi sosial dan memfokuskan kembali pada wilayah-wilayah signifikan dalam kehidupan sosial yang lebih umum seperti hiburan dan konsumerisme dalam lingkungan domestik. Sikap konsumtif inilah yang selanjutnya dapat membuat manusia serakah materi yang akhirnya merusak hubungan manusia-manusia.

Menjadikan masjid sebagai basis aktifitas sosial juga nyatanya berhasil dijalankan oleh Rasulullah saw. Beliau telah sukses mengubah dan membangun sebuah masyarakat melalui gerakan dakwah dari masjid yang tidak hanya menjadikan masjid sebagai pusat ibadah, tetapi juga menjadikan masjid sebagai pusat kebudayaan masyarakat Islam. Mulai dari pusat kegiatan umat, tempat pendidikan, pengembangan ekonomi umat, kesehatan umat dan ketahanan umat (Ali, 2017, hal. 8). 
Kondisi masjid-masjid di beberapa daerah di Kudus mengalami peningkatan dari segi kuantitas yang sangat baik. Pemfungsian masjid menjadi pusat kegiatan keibadahan juga masih sangat baik diselenggarakan beberapa masjid di Kudus. Tetapi menjadikan masjid sebagai pusat kebudayaan masyarakat Islam belum sepenuhnya berlaku di Kudus. Beberapa masjid yang dijadikan sebagai pusat kegiatan di luar peribadahan yang bersifat vertikal nampak dalam kegiatan sehari-hari di masjid menara Kudus. Lingkungan disekitar masjid yang sarat nuansa wirausaha dari mulai lapak yang menjual baju, tasbih, kitab, makanan, buku dsb. Bisnis di bidang jasa pun cukup ramai seperti misalnya bidang bordir kemena, jilbab atau juga percetakan menjadikan masjid menara Kudus memiliki gaya eksentrik tersendiri. Selain itu, rumah di sekitar masjid menara kudus juga kerap dijadikan tempat berlatih seni kaligrafi. Tradisi buka luwur juga tidak bisa lepad dari keberadaan masjid menara Kudus. Keberadaan masjid menara kudus yang dapat 'hidup' bersamaan dengan aktifitas harian masyarakat Kudus yang majemuk di luar kegiatan ibadah vertikal sangat kental semakin terasa dengan adanya Kelenteng Hok Ling yang hanya berjarak sekitar 300 meter dari Menara Kudus. Klenteng (Bio) Hok Ling kini menjadi salah satu tempat ibadah bagi umat tri dharma Kudus dan sekitarnya.

Selain masjid menara Kudus, masjid di Kudus yang dijadikan pusat kebudayaan adalah masjid Jami at-Taqwa yang berada di desa Loram Kulon. Masyarakat menyebutnya dengan tradisi mubeng Gapura yaitu tradisi mengelilingi gapura dalam adat prosesi pernikahan. Selain mubeng Gapura, di masjid ini terdapat tradisi iringiringan Ampyangan dan nasi kepel. Ampyangan merupakan pesta rakyat sebagai wujud syukur atas rizki yang telah diterima dari Allah swt. Sedangkan tradisi nasi kepel berawal dari kebiasaan warga sekitar yang memberikan makanan kepada pekerja di masjid, namun pada perkembangannya nasi kepel sering diganti dengan uang tunai sehingga pengelola masjid menyediakan kotak amal khusus betuliskan kas manten dan kepel.

Mahsun (2016, hal. 30-31) mengungkapkan bahwa tradisi Mubeng Gapura di Masjid At-Taqwa di desa Loram Kulon tersebut dalam tataran praktis dapat menjadi media peleraian konflik yang terjadi dalam individu maupun kelompok. Warga yang awalnya memiliki perselisihan satu sama lain akan lupa apabila sudah sama-sama dalam 
satu acara atau sama-sama melakukan tradisi ampyangan secara berdampingan dan sudah melupakan konflik tersebut. Masyarakat Loram Kulon walaupun bisa dikatakan sebagai masyarakat yang agamis tetapi masih ada dari sebagian masyarakat yang awam mengenai agama dan cenderung vakum bahkan tidak pernah untuk melakukan ibadah ke masjid tetapi dengan adanya tradisi ini seolah semua masyarakat diberi kesempatan untuk hadir di masjid untuk melakukan tradisi baik berupa ampyangan, nasi kepel dan penganten mubeng.

\section{Transformasi Sosial Melalui Gerakan Dakwah}

Setiap agama pasti mempunyai misi untuk menyebarkan agamanya masingmasing, dalam agama Islam penyebaran agamanya disebut dakwah sedangkan dalam agama Kristen disebut konversi agama Kristen atau misionaris. Dakwah berarti menyeru, memanggil atau mengajak sesuatu, sebagaimana dijelaskan Hafi Ansori yang mengutip pengapat A. Hasyim dinyatakan bahwa dakwah yaitu mengajak orang lain untuk meyakini dan mengamalkan aqidah dan syariah Islam terlebih dahulu telah diyakini dan diamalkan oleh pendakwah sendiri (Arifin, 2016, hal. 5).

Dakwah dalam konteks transformasi sosial pada kenyataannya tidak bisa hanya dengan mengandalkan paradigma konvensional yang menempatkan peran dai terlalu besar dan agak kurang memperhatikan potensi atau target pada mad'u. Model-model dakwah yang dilakukan masih cenderung dominan mengembangkan tradisi dakwah lisan dan hanya terksesan menjadi sekedar 'upaya untuk menyampaikan', sementara kondisi masyarakat berubah atau tidak belum menjadi persoalan serius. Gencarnya gerakan dakwah yang dilakukan para $d a^{\prime} i$ dalam berbagai bentuk dan melalui beragam media di masyarakat selama ini, belum berbanding lurus dengan peningkatan kualitas moral masyarakat. Umat dipandang sebagai wadah kosong yang harus diisi degnan keyakinan dan nilai-nilai moral sehingga tak heran jika beragam forum dakwah seringkali tidak mampu membangkitkan minat-minat eksploratif serta kreatifitas berfikir kritis. Sesuatu yang sesungguhnya dibutuhkan untuk membangun tradisi intelektual dan upaya pemberdayaan umat ke arah yang lebih maju dan berperadaban (Sarbini, 2010, hal. 4). 
Visi dakwah adalah perbaikan kualitas kehidupan dalam segala aspeknya dan misinya adalah seluruh ritme kehidupan dapat berjalan sesuai dengan nilai-nilai keislaman dan nilai-nilai luhur budaya yang berkembang di masyarakat sehingga nilai keislaman dan nilai luhur budaya yang harus dijadikan panduan dalam kehidupan manusia tidak hanya mewujud dalam kumpulan doktrin tapi benar-benar mewujud dalam ranah kehidupan nyata di masyarakat (Sarbini, 2010).

Gerakan dakwah perlu diorientasikan bukan hanya pada tataran tekstual akan tetapi kontekstual. Dakwah untuk pemberdayaan masyarakat (Majid, 2011, hal. 31) adalah pertama, gerakan dakwah yang bersifat tindakan nyata untuk mewujudkan perubahan yakni peningkatan kualitas keagamaan dan kualitas sosialnya, kedua, gerakan dakwah yang dilakukan secara profesional dalam sebuah lembaga dakwah dengan menerapkan fungsi-fungsi manajemen modern, ketiga, gerakan dakwah dapat berupa pendampingan dengan melibatkan berbagai pihak, keempat, da'i dalam gerakan dakwah dapat bertindak sebagai motivator dan fasilitator, kelima, yang menjadi sasaran dakwah pemberdayaan adalah masyarakat yang memiliki kondisi lemah dan keenam, materi dakwah tidak hanya materi keagamaan (misal keislaman) tetapi juga meliputi berbagai aspek yang menyangkut peningkatan kualitas hidup manusia.

Masdar dalam Sarbini (Sarbini, 2010) Paradigma baru dakwah harus dimaknai sebagai proses penyadaran tidak hanya melalui ucapan melainkan sikap, laku, aksi dan teladan. Kuntowijoyo dalam Amin (2009, hal. 163) menjelaskan bahwa proses dakwah harus mampu mengembalikan dan mengembangkan lima tradisi penting dalam kehidupan masyarakat yakni pertama, tradisi rasional, kedua tradisi egalitarian, ketiga tradisi berbudaya, keempat tradisi ilmiah dan kelima tradisi kosmopolitan. Langkah yang dapat dilakukan adalah dengan menerapkan model dakwah yang dibangun dan dikembangkan di atas pilar nilai agama (Islam) dan pilar kebudayaan yang melingkupinya. Dengan kata lain, sebagai sebuah gerakan yang mempengaruhi perubahan sistem sosial, gerakan dakwah harus mampu memerankan dua fungsi yaitu turut melestarikan nilai-nilai budaya tradisional dan melakukan transformasi masyarakat yang sesuai dengan nilai agama sehingga masyarakat mampu menghadapi tantangan jaman dan mampu membangun peradaban. 
Bagi masyarakat Kudus, ada banyak tradisi keagamaan yang diselenggarakan pada hari-hari tertentu sekalipun tradisi keagamaan masih banyak didominasi oleh masyarakat muslim (ini karena mayoritas masyarakat Kudus beragama Islam). Sebut saja misalnya tradisi rebo wekasan, waqi ahan, bukak luwur, dhandangan, bancakan sewu ketupat, tradisi wiwit kopi, Rogomoyo, bulusan, Bodo Kupat, Tradisi resik-resik Sendang dan Nyiwer Desa, Tradisi Tebokan Jenang Kudus, Tradisi Ampyang Maulid. Untuk memperingati Syawalan saja, Kudus memiliki lima tradisi yang berbeda di beberapa daerah di Kudus yaitu Desa Colo (Kecamatan Dawe) yang memiliki tradisi kirab seribu ketupat, Desa Hadipolo (Kecamatan Jekulo) dengan tradisi bulusan, desa Kesambi (Kecamatan Mejobo) dengan tradisi lomban (pesta sungai), Desa Wonosoco (Kecamatan Undaan) dengan tradisi sendang dewot, dan Desa Purworejo (Kecamatan Bae) dengan tradisi sendang jodoh.

Kabid Pariwisata Dinas Kebudayaan dan Pariwisata Kabupaten Kudus Sancaka Dwi Supani mengatakan bahwa dengan adanya beragam tradisi yang sarat nilai-nilai luhur budaya, masyarakat Kudus tidak hanya turut menjaga kelestarian budaya lokal melainkan turut menggerakkan roda perekonomian warga sekitar lokasi karena di sekitar lokasi perayaan sering dimanfaatkan untuk berjualan aneka kebutuhan masyarakat (Rachman, 2011, hal. 1).

Setiap penyelenggaraan tradisi-tradisi di Kudus selalu tidak sepi pengunjung. Ini menunjukkan bahwa masyarakat Kudus masih membutuhkan keberadaan tradisitradisi tersebut. Tentu banyak ragam motivasi yang melatarbelakangi ketertarikan masyarakat dalam acara tradisi-tradisi tersebut. Robi misalnya, salah satu masyarakat Kudus pengamal tradisi waqi ahan yang berupa tradisi pembacaan surat al waqiah yang dilakukan oleh beberapa masyarakat yang meyakini adanya keberkahan tertentu dari pembacaan surat Al Waqiah, mengungkapkan bahwa waqi ahan dapat menjadi media untuk meningkatkan solidaritas kelompok masyarakat tertentu sekaligus sebagai penyeimbang aktifitas duniawi terutama bila dikaitkan dengan pekerjaan.

Mengikuti rangkaian tradisi-tradisi tersebut juga dapat melatih kecerdasan afektif seseorang. Mengikuti tradisi-tradisi seperti bukak luwur dapat meningkatkan kepedulian terhadap sesama (tepa selira), melatih kesediaan untuk berkorban dan tidak 
mementingkan diri sendiri, juga meningkatkan kesadaran akan persamaan (egaliter) hakikat manusia. Tentu, tak sedikit juga yang memaknai tradisi-tradisi tersebut dengan hanya sekedar tradisi rutinan atau formalitas belaka, yang dilakukan setiap tahun atau secara berkala, bahkan ada pula yang menganggap tradisi bodo kupat yang ditandai dengan pembuatan ketupat di hari ketujuh syawal dianggap sebagai kegiatan yang tidak praktis dan membutuhkan waktu yang lama. Tetapi bodo kupat masih banyak masyarakat Kudus yang berusaha untuk tidak melewatkannya meski terulang setiap tahun. Selain tradisi sosio-religio-kultural yang tersebut di atas, image gusjigang (singkatan dari bagus, ngaji dan pinter dagang) yang mewakili figur sunan kudus menjadi teladan dan panutan masyarakat Kudus agar senantiasa memiliki kepribadian yang tidak hanya berkualitas dari segi fisik tetapi juga berkualitas dari segi ruhaniah ditambah dengan memiliki jiwa kemandirian dan tanggungjawab yang dapat ditunjukkan dengan kegiatan dagang atau wirausaha.

\section{Lembaga Pendidikan Agama sebagai Sentral Pendidikan Karakter}

Merujuk pada rumusan tujuan pendidikan nasional, nilai sentral yang dirujuk sebagai dasar dan tujuan pendidikan karakter adalah nilai-nilai yang bersumber dari agama. Artinya karakter yang ingin dibentuk adalah karakter yang berdasar ajaran agama yakni beriman, bertakwa dan berakhlak mulia. Karena agama menjadi referred value, maka pembelajaran agama harus menjadi bagian tak terpisahkan dalam proses pembelajaran di sekolah. Pengesampingan dan pengabaian pendidikan agama akan berpeluang menimbulkan ketidakseimbangan antara capaian kognitif (intelektual) dan Afektif (kepribadian). Sistem pendidikan madrasah adalah model pendidikan karakter atau pendidikan berbasis karakter yang cocok untuk kondisi di Indonesia, karena secara empiris lembaga pendidikan ini sudah ada lama sebelum Indoneisa merdeka. Oleh karenanya model pendidikan ini bida dikembangkan dan diadopsi untuk diterapkan dalam sistem persekolahan di Indonesia (Supa at, 2014, hal. 223).

Keberadaan madrasah-madrasah di Kudus masih menjadi sekolah favorit bagi para orang tua yang hendak menyekolahkan anaknya. Tujuan orang tua memilih Madrasah sebagai sekolah pilihan tentu berkaitan dengan kualitas dan kuantitas bekal pemahaman keagamaan yang dapat diperoleh anak lebih baik daripada sekolah sekolah 
umum. Madrasah dianggap mampu mengendalikan para siswanya untuk tidak mengikuti trend life style kekinian. Sebagai contoh, pada peringatan kelulusan sekolah ditingkat menengah ke atas dengan parade konvoi dan pilox yang tidak tampak dilakukan oleh para siswa dari madrasah tertentu di Kudus tetapi kegiatan tersebut dilakukan oleh sekolah umum tertentu di Kudus.

Meski demikian, pendidikan agama masih belum sepenuhnya berjalan efektif sekalipun sudah melakukan berbagai macam perbaikan misalnya melalui penyediaan tenaga pendidik, pelatihan bagi pendidik bidang agama dsb. Hal tersebut antara lain disebabkan oleh kurikulum pendidikan agama yang lebih menekankan aspek kognitif dan kurang memperhatikan aspek pengamalan ajaran agama dalam pembentukan akhlak dan karakter. Padahal proses penerapan nilai-nilai universal harus melalui moral knowing, moral loving dan moral acting/doing. Sebab memiliki pengetahuan tentang kebaikan saja belum cukup mampu mendorong seseorang berkelakuan baik. Pengajaran agama juga perlu diselenggarakan dengan memperhatikan tiga elemen penting dalam diri peserta didik (masyarakat) yaitu pengalaman (experience), imajinasi (imagination), dan pemikiran (thinking). Tiga pendekatan ini mengganti proses indoktrinasi dalam pendidikan agama yang selama ini dilakukan oleh beberapa lembaga pendidikan ataupun dakwah sekalipun.

Pendidikan agama harus dapat membantu manusia untuk mempunyai sikap empati sehingga pendidikan memerlukan pendekatan imajinasi yang membantu seseorang dapat memahami pengalaman orang lain. Sementara pengalaman adalah komponen dasar dalam membangun saling pengertian. Adanya pengalaman dan imajinasi tersebut merangsang seseorang untuk berfikir dan merenung. Dengan demikian tujuan pendidikan agama bukan dimaksudkan untuk mengarahkan seseorang menjadi beragama atau hanya memiliki agama, akan tetapi membantu seseorang untuk memahami eksistensi agama yang pada akhirnya memberikan dampak pada pembentukan moralitas atau karakter bangsa.

\section{Potensi Harmoni Antar Organisasi Keagamaan di Kudus}

Ada banyak organisasi keagamaan dan aliran kepercayaan yang berkembang di Kudus. Organisasi di bawah naungan NU seperti Banser, Fatayat, Muslimat, IPPNU, 
IPNU, demikian juga organisasi di bawah naungan Muhammadiyah, Nasiyatul Aisiyah, Aisiyah. Terdapat juga organisasi lintas agama atau Forum Komunikasi Umat Beragama (FKUB) dan kelompok-kelompok dari aliran yang dianggap sesat oleh MUI Jawa Tengah.

Penelitian Rosyidi (Rosyidi, 2013) mengungkapkan bahwa masyarakat yang beragama baik yang agamanya resmi diakui oleh negara ataupun yang dianggap sesat oleh MUI masih berpotensi untuk tetap hidup harmonis. Faktor pendukung kerukunan beragama terwujud karena antar-pemeluk agama dan atau intern agama yang berbeda aliran terdapat hubungan persaudaran (geneologia), terjadi simbiosis mutualisme di bidang perekonomian, pemahaman dalam batin antar pemeluk agama dan atau intern agama yang berbeda aliran diwujudkan dalam kehidupan dengan megnedepankan persamaan kebutuhan dan menafikan konflik yang lazimnya dipicu oleh perbedaan keyakinan dan agama, pola pikir antar pemeluk agama dan atau intern agama yang berbeda aliran terjauhkan dari sikap negatif (Rosyidi, 2013, hal. 58).

Sementara faktor penyebab terjadinya konflik antar pemeluk agama dan atau intern agama yang berbeda aliran adalah pertama, adanya pemicu konflik. Pemicu konflik bukan pada adanya perbedaan baik agama, sikap, argumentasi dsb. Akan tetapi ketidakmampuan masyarakat menerima perbedaan tersebut seperti yang terjadi di Desa Getas Pejaten, warga menolak pemanfaatan ruko sebagai tempat ibadat umat kristiani karena pemanfaatan ruko sebagai tempat ibadah menyalahi fungsi bangunan ruko itu sendiri (Rosyidi, 2013). Kedua, sumber konflik yang tidak tertangani. Terjadinya konflik di Indonesia sering dipicu oleh persoalan sederhana seperti pertikaian kelompok pemuda, kekalahan dalam pertandingan dsb. Ketiga, perilaku agresif yang tidak terantisipasi. Pada dasarnya, ketika seseorang menempuh jalan kekerasan disebabkan karena faktor kemampatan berfikir. Kekerasan hanyalah cara ketika tidak ada jalan lain. Keempat, pemicu kekerasan tidak teredam. Secara sosiologis terdapat tida faktor pemicu kekerasan yakni keyakinan, institusi dan ritualisme. Ketika agama berada pada level sistem keyakinan maka tidak ada persoalan. Ketika agama berada pada level institusi agama, muncullah rezim kekuasaan dalam penafsiran tentang kebenaran yang memunculkan konflik. Problem struktural dan ketidakmapanan bidang ekonomi, 
pemahaman keagamaan dan politik yang menafikan budaya lokal dan ketidakdewasaan kelompok mudah mencuatkan kekerasan (Rosyidi, 2013, hal. 62).

Belajar hidup harmonis antar pemeluk agama dan atau intern agama yang berbeda aliran di daerah Colo, Kudus. Terdapat satu komunitas aliran beragama yang difatwa sesat oleh MUI pusat tetapi tidak ditolak oleh warga Kudus secara terbuka yakni Ahmadiyah yang berada di Desa Colo, meskipun telah diterbitkan surat keputusan bersama oleh tiga lembaga negara yakni Menteri Agama, Menteri Dalam Negeri, dan Jaksa Agung Nomor 3/2008; Nomot 199/2008; dan Nomor KEP-033/A/JA/6/2008 pada Juni 2008. Konflik sosial tidak terjadi di desa Colo karena pertama, sumber ekonomi dan strata ekonomi merata, sehingga tidak terjadi kesenjangan ekonomi, kedua, pemahaman keagamaan warga Desa Colo tidak kategori fanatis karena rata-rata pengetahuan keislamannya tidak eksklusif, ketiga, tidak adanya kelompok sosial yang menonjol dalam aspek jumlah atau perasn sosial sehingga tidak terjadi kepongahan peran organisasi sosial (Rosyidi, 2013, hal. 62). Selain harus mampu beriteraksi dengan antar organisasi keagamaan, organisasi-organisasi keagamaan juga harus mampu melakukan koreksi terhadap orientasi visi dan misi organisasi keagamaan. Dalam sebuah seminar yang diselenggarakan oleh Pusat Studi Perdamaian dan Resolusi Konflik Universitas Gadjah Mada dengan topik "Muhammadiyah dan Keberpihakan pada Wong Cilik" membahas bahwa lembaga layanan umat yang berada di bawah organisasi keagamaan, sejak beberapa tahun terakhir mulai kehilangan rohnya, meninggalkan keberpihakan pada kaum miskin atau orang kecil dan lebih berorientasi pada profit atau kapital (Pusat Studi Pedesaan dan Kawasan Universitas Gadjah Mada, 2010).

Pada beberapa Madrasah di bawah naungan organisasi keagamaan di Kudus pun dijumpai hal yang sama. Hanya orang dengan status ekonomi menengah ke atas yang mampu menyekolahkan anak-anaknya di sekolah tersebut karena besarnya biaya pendidikan yang dibebankan kepada orang tua. Kecenderungan menganut faham pragmatisme merupakan faktor utama yang menyebabkan terjadinya pergeseran tersebut. Kecenderungan ini sebenarnya tidak hanya melanda organisasi keagaman yang berbasis Islam namun juga organisasi keagamaan yang non-Islam. Salah satu indikator adanya pergeseran tujuan yang ingin dicapai oleh organisasi keagamaan dari tujuan 
mulia memberi pelayanan kepada umat khususnya orang miskin dan orang kecil ke arah pencapaian kepentingan yang bersifat sesaat (kepentingan ekonomi dan politik) adalah gencarnya upaya untuk mendorong organisasi keagamaan tersebut untuk terjun ke dunia politik praktis, baik secara langsung nampak dari adanya fenomena pembentukan partai politik yang diharapkan dapat memobilisasi anggota orgasnisasi untuk mencapai kepentingan politik atau paling tidak dapat menjadi saluran kepentingan politik anggota organsiasi terseut. Tampilnya beberapa tokoh partai politik dalam bursa oemilihan ketua pengurus pusat organisasi juga merupakan indikator dari adanya upaya untuk menarik gerbong organisasi ke dunia politik. Paling tidak menjadikan organisasi sebagai basis kekuatan untuk mencapai kepentingan politik. Indikator lain yang dapat dijadikan petunjuk adanya upaya untuk meraih kepentingan politik sesaat adalah disampaikannya undangan kepada pejabat negara untuk memimpin pembukaan muktamar dan pemberian status keanggotaan istimewa kepada pejabat negara. Ini adalah tantangan organisasi keagamaan agar bagaimanapun juga dalam visi dan misinya tetap memperjuangkan nilai-nilai universalitas yang tertuang dalam ajaran masing-masing agama.

Komunikasi pemberdayaan masyarakat juga mempengaruhi proses dan keberhasilan pemberdayaan masyarakat beragama. Komunikasi pemberdayaan masyarakat merupakan kajian yang lebih fokus pada pentingnya pelibatan masyarakat atau partisipasi masyarakat (Indardi, 2016). Pelibatan masyarakat ini dinilai akan lebih efektif untuk mencapai keberhasilan suatu tujuan. Jika diamati lebih mendalam, dari atribut keagamaan di atas antara tempat-tempat peribadatan, lembaga dakwah, Lembaga pendidikan agama dan tradisi, pemberdayaan masyarakat beragama melalui tradisi masih efektif untuk tetap terus dilakukan. Sementara atribut keagamaan yang lain masih belum efektif. Hal ini bisa jadi karena pelibatan masyarakat dalam kegiatankegiatan di tempat-tempat peribadatan, lembaga dakwah dan lembaga pendidikan agama, kurang. Dalam pemberdayaan masyarakat, berbagai kegiatan lebih menempatkan masyarakat sebagai subjek yang memiliki berbagai sisi kemanusiaannya baik berupa keinginan, cita-cita, daya, nilai-nilai, budaya dan sebagainya. Oleh karena itu, agar potensi keberagamaan masyarakat di Kudus semakin mampu memperkuat 
ideologi pancasila, partisipasi masyarakat beragama di Kudus masih diperlukan di seluruh atribut keagamaan.

Secara keseluruhan dapat disimpulkan bahwa menerapkan budaya berbasis nilai-nilai universal, agama harus ditempatkan dalam kontruks lokalitasnya. Penjabarannya sebagai berikut, pertama, agama harus menampilkan ajarannya yang memiliki moralitas universal. Universalitas mengusung tema moralitas agama. Agama apapun akan mengajarkan kemanusiaan, cinta dan kasih sayang, keadilan, kesetaraan, keselamatan dan perdamaian. Persoalan kemanusiaan adalah persoalan universal, sehingga harus diusung oleh semua pemeluk agama. Kedua, menggalang pemahaman agama yang tidak sempit (bukan hanya tataran teologis) dengan klaim kebenaran yang eksklusif. Kesadaran itu bersumber dari pemahaman bahwa ada perbedaan teologis dan ritual yang tidak terbantahkan, tetapi juga ada dimensi humanitas yang dapat dipertemukan. Faham agama yang eksklusif akan berimplikasi terhadap penyangkalan diversitas kepemelukan agama yang memang menjadi keniscayaan di dunia ini. Ketiga, agama (masyarakat beragama) perlu mengembangkan sikap keberagaman yang moderat. Moderatisme adalah sikap keberagamaan yang cenderung memberikan ruang lain dengan keyakinan berbeda, pandangan hidup berbeda dan gaya hidup berbeda adalah suatu kewajaran dan kemungkinan di dalam kehidupan. Akhirnya, tidak berlebihan kiranya menempatkan Kudus sebagai salah satu potret keberagamaan melalui pemberdayaan masyarakat beragama yang dapat menjadi contoh dalam rangka pengembangan wawasan keberagamaan yang moderat yang dapat memperkuat ideologi pancasila (Nasir \& Syam, 2004, hal. 266).

\section{Simpulan}

Pemberdayaan masyarakat beragama perlu dilakukan segera mungkin untuk membantu meningkatkan kualitas keberagamaan masyarakat. Kualitas keberagamaan masyarakat harus didasarkan pada aktualisasi nilai-nilai universal agama. Nilai-nilai universal adalah sifat dasar spiritual manusia seperti kemampuan manusia untuk menyayangi, menghargai sesama, keadilan, kejujuran, kemuliaan, kasih sayang, tanggung jawab dsb. Kualitas keberagamaan masyarakat tersebut akan memperkuat 
ideologi Pancasila sebagai budaya bangsa yang pada akhirnya dapat membantu meminimalisir degradasi moral bangsa.

Pemberdayaan masyarakat beragama dilakukan melalui berbagai tahapan yakni pertama, menciptakan suasana atau iklim yang memungkinkan potensi masyarakat berkembang (enabling). Kedua, memperkuat potensi atau daya yang dimiliki masyarakat (empowering). Ketiga, pemihakan terhadap yang lemah harus menjadi prioritas dalam pemberdayaan masyarakat. Untuk menempuh tahapan-tahapan tersebut dapat memanfaatkan berbagai atribut keagamaan yang sudah tersedia misalnya tempat-tempat peribadatan, lembaga pendidikan, lembaga sosial dan organisasi keagamaan dsb dengan mengupgradenya melalui pendekatan berbasis nilai-nilai universal. 


\section{Referensi}

Ali, Z. M. (2017). Masjid Sebagai Pusat Pemberdayaan Masyarakat. Diambil dari https://media.neliti.com/media/publications/40273-ID-masjid-sebagai-pusatpembinaan-umat.pdf

Amin, S. (2009). Ilmu Dakwah. Jakarta: AMZAH.

Arifin, S. (2016). Dakwah Islam sebagai Upaya Penangkalan Kristenisasi. Dakwatuna: Jurnal Dakwah dan Komunikasi Islam, 2(1).

Aziz, A. . (2004). Nilai dan Etika Pengurusan: Analisa dari Perspektif Agama-agama di Malaysia. Malaysia.

Conolly, P. (2009). Aneka Pendekatan Studi Agama. Yogyakarta: Lkis.

Ginanjar, A. (2004). Rahasia Sukses Membangkitkan ESQ Power. Jakarta: Arga.

Indardi. (2016). Komunikasi Pemberdayaan Masyarakat. Bandung: UNPAD Press.

Liauw, H. (2015). Bangsa Membutuhkan Pencerahan Spiritual.

Mahsun, M. (2016). Solidaritas Sosial Masyarakat dalam Tradisi Pernikahan Mubeng Gapura Desa Loram Kulon Kabupaten Kudus. Universitas Islam Negeri Sunan Kalijaga.

Majid, A. (2011). Pendidikan Karakter Perspektif Islam. Bandung: Rosda Karya.

Megawangi, R. (2004). Pendidikan Karakter: SOlusi yang Tepat Membangun Bangsa. Jakarta: Star Energy (Kakap) Ltd.

Muthohar, S. (2013). Antisipasi Degradasi Moral di Era Global. Pendidikan Islam, 7(2).

Nasir, R., \& Syam, N. (2004). Institusi Sosial di Tengah Perubahan. Surabaya: Jenggala Pustaka Utama.

Nurhadianto. (2014). Internalisasi Nilai-nilai Pancasila dalam Upaya Membentuk Pelajar Anti Narkoba. Pendidikan Ilmu Sosial, 23(2).

Nurjamila, C. (2016). Pemberdayaan Masyarakat Berbasis Masjid dalam Perspektif Dawkah Nabi Saw. Journal of Islamic Studies and Humanities, 1(1). https://doi.org/10.21580/jish.11.1375

Pusat Studi Pedesaan dan Kawasan, P. (2010). Pragmatisme: Godaan Terberat Organisasi Keagamaan di Masa Kini. 
Rachman, T. (2011). Kudus, Satu Kota dengan Lima Tradisi Syawalan. Republika.

Rosyidi, M. (2013). Harmoni Kehidupan Sosial Beda Agama dan Aliran di Kudus. Addin, 7.

Sarbini, A. (2010). Paradigma Baru Pemikiran Dakwah Islam. Jurnal Ilmu Dakwah, 4.

Solikhin, M. (2015). Berbagai Masalah Keberagamaan Masyarakat Modern dalam Perspektif Dekonstruksi Dawkah Berbasis Psikologi Sosial. Komunika, 9(1).

Supa`at. (2014). Model Kebijakan Pendidikan Karakter di Madrasah. Jurnal Pendidikan Islam, III.

Sutaryo, Jaya, W. K., Swasono, S. E., Baswir, R., \& Prijambada, I. D. (2015). Membangun Kedaulatan Bangsa Berdasarkan Nilai-nilai Pancasila: Pemberdayaan Masyarakat Dalam Kawasan Terluar, Terdepan, dan Tertinggal (3T): Kumpulan makalah call for papers kongres Pancasila VII. Pusat Studi Pancasila Universitas Gadjah Mada.

Tasmara, T. (2001). Kecerdasan ruhaniah (transcendental intellegence): membentuk kepribadian yang bertanggung jawab, profesional, dan berakhlak. Jakarta: Gema Insani Press.

Teknik Pemberdayaan Masyarakat Secara Partisipatif. (2002). Departemen Agribisnis FEM IPB. 
Halaman ini bukan sengaja untuk dikosongkan 